\title{
Study of pervasive developmental disorders among students in Mosul city
}

\author{
Sahar K. Omar \\ Department of Pediatrics, College of Medicine, University of Mosul.
}

(Ann. Coll. Med. Mosul 2012; 38 (2): 52-61).

Received: $12^{\text {th }}$ Jun. 2011; Accepted: $7^{\text {th }}$ Feb. 2012.

\begin{abstract}
Objective: To detect cases of pervasive developmental disorders among a sample of primary school students in Mosul city.

Design and method: A descriptive study including 137 students boys and girls of the second class in AlThawra, Al-Ghazali and Abi-Tamam primary schools.

A questionnaire paper was used which was filled by the teachers after discussing all the matters with them by the investigator. Rechecking was done and evaluation of the three categories involved in the paper (social interaction difficulties, language defects and conduct disorders). The students were divided into three groups according to the scores on the items of the scales. Group three with high marks in some questions $(3,4)$ were studied further including any risk factors for their defects, their midyear exam results and their marks in Arabic language. Statistical analysis was done to evaluate the collected data.

Results: No case of autism or related disorder was detected. Other problems were detected which were more among males. The commonest problems were being aloof with their own world and excessive fear of noises. Two boys in Al-Thawra school had some conduct disorders and another two had delay in language and speech. Those with language defects had low marks in Arabic language of midyear examination.
\end{abstract}

Conclusion: Problems in social interactions, speech and behavior were important to look for among students which may affect their progress at school.

\footnotetext{
الخلاصة

الهذف: البحث عن حالات الاضطر ابات النمائية واسعة الانتشار في نموذج من طلبة المدارس الابتدائية في مدينة الموصل.

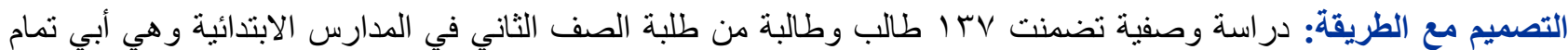
النموذجية، الثورة للبنين و الغز الي للبنات دراته تم استعمال ورقة استبيان ملئت من قبل مرشدات الصفوف بعد شرح كافة النقاط معهن من قبل الباحث ثم نم مراجعة النتائج

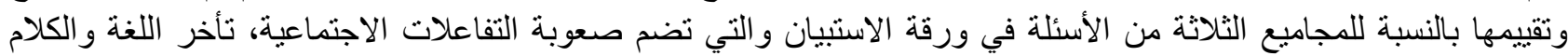

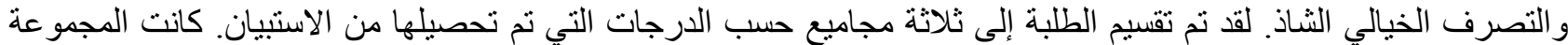

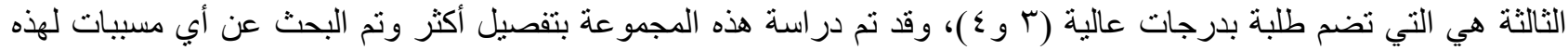

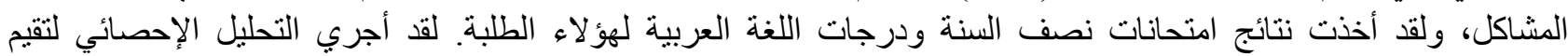
المعلومات التي تم جمعها.

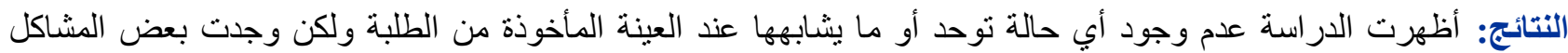

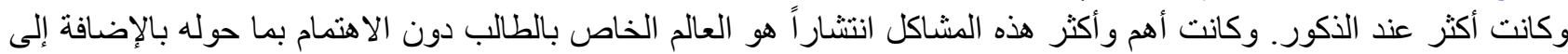

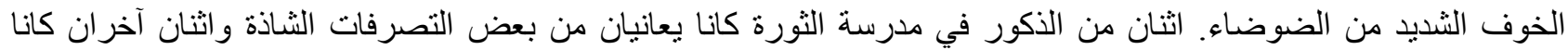
يعانيان من مشاكل في اللغة و الكلام. لقد حصل الطلبة الذين لديهم مشاكل في اللغة على درجات قليلة في اللغة العربية في امتحان نصف السنة
} 


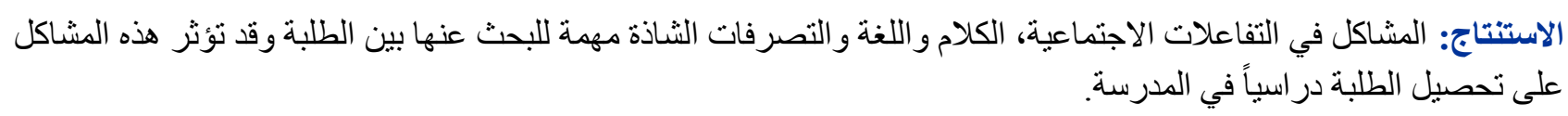

$\mathrm{P}$ ervasive developmental disorders are a spectrum of disabilities with childhood autism at the severe end and Asperger syndrome at the mild end ${ }^{(1)}$. First described by Kanner 1945, these disorders have 3 features that are essential to the diagnosis: general and profound failure to develop social relationships, language retardation and ritualistic and compulsive behavior; all should be manifested before 30 months of age ${ }^{(1)}$. These disorders can be seen in all socioeconomic groups, boys more affected than girls, the prevalence rate of all these disorders was $58.7 / 10000$ children, but the incidence of the diagnosis of autism may have increased and information from the national institute of mental health and the center for disease control and prevention 2007 indicates that from 1 in 500 to 1 in 150 children have some form of pervasive developmental disorders, this increase is likely related to changes in the definition and diagnostic criteria for autism as well as improvements in the recognition of autism at younger ages ${ }^{(1,2)}$. Recurrence is $10-20 \%$ in subsequent siblings, genetic risk for second child with autism is $5 \%$, there is $60-90 \%$ concordance rate for autism for monozygotic twins and $0 \%$ concordance rate for dizygotic twins ${ }^{(2,3)}$

The exact cause of autism is unknown but it is believed to be multifactorial with a strong genetic influence, the genetic abnormalities have been identified in mitochondrial genes and in all chromosomes except 14 and $20^{(1,2)}$.

Many patients with autism are identified with specific genetic disorders ${ }^{(4)}$, non-specific EEG abnormalities are common even without seizures ${ }^{(5)}$, as well as with non specific abnormalities on brain scan ${ }^{(3)}$. In rare cases, it is strongly associated with agents that cause birth defects ${ }^{(6)}$. Controversies surround other proposed environmental causes for example heavy metals as lead, pesticides, certain foods, alcohol, smoking, infectious disease, increase in several growth hormones and diminished growth factors and MMR vaccine, although excellent studies found no association between the administration of MMR and development of autism ${ }^{(2,7,8)}$. Autistic behavior occurs in some patients with a diverse group of conditions including the fragile $X$ syndrome, congenital rubella, phenylketonuria, tuberose sclerosis, neurolipidoses, infantile spasms, hearing defects and language disorders. $(1,2.5)$.

During infancy the child is slow to smile, lack of recognition of mother voice, unresponsive and passive with dislike of physical contact and affection with failure to use eye to eye gaze and rarely seeking others for comfort or affection (1). Babbling may be absent or if present it is of lower quality and frequency than in peers ${ }^{(9)}$. Most children have normal appearance other than macrocephaly in about $25 \%{ }^{(3)}$.

Some children seem totally aloof, others may show intermittent engagement with their environment, smile and hug. They may be nonverbal or they may have advanced speech and imitate songs and TV commercials. The speech may have an odd prosody and may be characterized by echolalia and idiosyncratic forms, there is failure to orient to name and failure to use gestures to point to wave or to show ${ }^{(2)}$.

There may be mental retardation $(70 \%)$, some have hyperlexia where the child has a reading age beyond their peers but with trouble in understanding the meanings of words used, some show strength in art, music and puzzles ${ }^{(2,9)}$. Stereotypical body movements, marked need for sameness and a very narrow range of interest, tantrum like rages may accompany disruptions of routine ${ }^{(2)}$.Visual scanning of hand, mouthing of objects and rubbing of surfaces may indicate sensitivity to some stimuli. Hypersensitivity explains the child who clamps his hands over his ears every time the phone rings or who refuses to eat certain texture of food. Hyposensitivity is displayed in the child oblivious to temperature or with a high pain threshold. The senses of smell and taste may be used to inspect new objects and people ${ }^{(2,9)}$. Sleep problems affect about $2 / 3$ of individuals with autistic spectrum disorders at some point in childhood ${ }^{(10)}$. Autistic children often exhibit a variety of stereotypes including rocking, finger twirling, spinning and tiptoe walking. Of 
others self stimulatory behaviors are hand flapping, teeth grinding, jumping from foot to foot ${ }^{(1,9)}$. About $20 \%$ will develop epilepsy during adolescence although not usually severe, common comorbidities are anxiety, hyperactivity and obsessive compulsive disorders ${ }^{(1,5)}$.

Although there is no known cure but early behavioral intervention can help autistic children gain self care, social and communication skills, this therapy should begin before 3 years of age ${ }^{(2,11)}$. The prognosis is guarded, there are no known methods of primary prevention but delayed diagnosis may lead to poor outcome. Special diets can be helpful sometimes for some children but not for all ${ }^{(12)}$. Some children may grow up to live self sufficient employed albeit isolated lives and many adults develop impressive talents, even many children do improve to the point where they lose the diagnosis (12). But many others remain dependent on their family and may require placement in facilities outside home. There is no increased risk of schizophrenia in adulthood but the symptom profile may change as the child grows older and seizures or self injurious behavior become more common ${ }^{(2,5)}$.

\section{Aims of the study}

1. To identify any case of pervasive developmental disorders among a sample of primary school students in Mosul city.

2. To correlate between some variables and the academic progress at school.

\section{METHODOLOGY}

A descriptive study of 137 , second class students from three primary schools in AL-Tayaran and ALGhazlany areas of Mosul city, they where AbiTamam AL- namothyjia, AL-Thawra for boys and $A L-G h a z l a n y$ for girls, they were chosen randomly using PDD scale ${ }^{(13)}$. Both sexes were included; their ages ranged 7-12 years. It was conducted over three months from $15^{\text {th }}$ January until $30^{\text {th }}$ march 2011. A questionnaire form was used which included the demographic characters of the students, as well as 15 questions for impairment in social interactions, 14 questions about language and speech delay and 15 ones for conduct disorders (Appendix $1 \&$ 2). Scoring was done on sports scale and scores $<2.5$ was regarded abnormal. Each mark had meaning as follows: $0=$ perfectly normal, never had such problem.
$1=$ perfectly normal, but used to belong to one of the categories.

$2=$ features minimally found or skills only minimally impaired.

$3=$ features present frequently or skill significantly impaired.

$4=$ feature present almost all the time.

The investigator had visited the three schools several times, and meetings were conducted with the guider teachers. Full discussion of the questionnaire paper was made with them explaining every point clearly. They were told to ask the mother help if needed. Data were collected from the three schools separately, rechecked by the investigator and re-evaluated with the teachers if needed. Personal meeting with some students was carried on to define the problem more clearly. For each school the studied sample was divided in to three groups, group (1) were those with zero marks in all the questions, group (2) were those with two marks in most of the questions, and group (3) were those with (3) \& (4) marks in some of the questions. The characters of each group was studied and comparison was done between them, any risk factor for any problem was looked for including the demographic characters, also the commonest problems for those with group (3) from the three schools were studied. The results of the midyear examination of those in group (3) and their marks in Arabic language were taken from their schools to correlate these marks, and delay in speech and language if present. Those students with zero scoring in all the questions, those with zero in some questions and one in others, as well as those with marks two in most of the questions were considered within the normal range.

Statistical analysis was used by finding $\mathrm{P}$-value to evaluate the results, it was considered abnormal if it was $<0.05$.

\section{RESULTS}

One-hundred thirty seven students were studied from the three schools. The total number of boys was 69 , of girls 68 , and male to female ratio was about $1 / 1$. Being of the of the $2^{\text {nd }}$ class their ages ranged from 7 - 8 years, few of them were repeaters for one time or more and their ages ranged 9-12 years. After analysis of the results of the questionnaire paper, no case with full blown picture of autism or related disorder was 
discovered but some problems had been found in the three schools in communication skills, language or behavior. The number of students with zero in some questions and one in others was 30 , (17 9 and $13 \hat{})$ ); they were not studied further. The remaining 107 students were of group (1,2 and 3), were further studied regarding age, sex and risk factors for their problems if present.

Table 1 shows sex distribution of the groups. There was a difference between number of males and females in the three groups; in group (1) there were more girls and in group (2) and (3) there were more boys. As number of brothers, number of sisters, father job and mother job besides sex could be considered as risk factors for these problems they were put in Tables 2 and 3 with comparisons between the three groups regarding these points where $p$ value was significant for some data.

As group (3) was considered abnormal more study of their problems were done, Table 4 (A, B, C) shows these problems for the three schools, where a common problem was present, excessive fear of noises was seen in (25\%) of students especially in girls, while being aloof with their own world was seen in $(38 \%)$ of students especially boys.

In Abi-Tamam, more problems were found, being a school of higher number of students, 11 students being aloof with their own world, 7 lack the curiosity about the environment, 6 ignore when called and 5 hate crowds. No significant defect in language and speech had been seen, but some conduct disorders were more common than others, including being obsessed with objects (25\%), and having interest in toy parts (25\%). Being a school of boys and girls the investigator tried to see if sex had any effect on the types of the problems. In girls their main problems were in social interactions, while boys had problems of conduct more than girls, beside their social interaction difficulties. The main language and speech problems for Abi -Tamam boys were producing unusual noises with loss of acquired speech, while for Al-Thawra school the problems in language were more serious including difficulty in understanding basic things, and in expressing needs with monotonus speech, and absence of imitation of communication. The main conduct disorders in boys of Abi-Tamam were being obsessed with objects, with interest in toy parts, while in Al-Thawra boys the behavior problems were more in types and seen in more students. Two boys in this school in group (3) had all the defects in language and speech in the assessment questionnaire paper, and another two students had conduct disorders in most of the questions of the imaginary behavior.

The students midyear examination results for group (3) were recorded from their schools, to find how many had passed the examination successfully, and how many had failure in one or more subjects, which could be due to their problems (Figure 1).

Also for group (3) the student's marks of midyear examination in Arabic language were recorded from the three schools to see the relation between their problems and their teaching, and understanding Arabic language - although all were arabic students -especially if there was a defect in language and speech. Table $\mathbf{5}$ shows the comparison between the three schools on which statistical analysis was done to evaluate the data, and to find the students who need help, whether speech therapy or some medicine, or psychotherapy, this was discussed with their teachers especially for Al-Thawra school of boys.

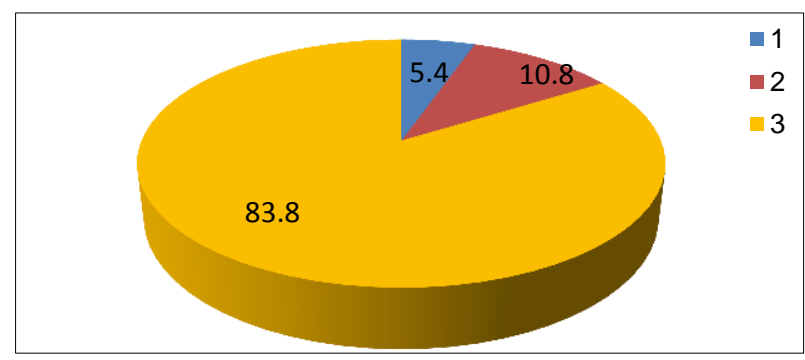

$1=$ Failure in one or more subjects $(5.4 \%)$.

2 = Total failure $(10.8 \%)$.

3 = Had passed the examination successfully (83.8\%).

Figure 1. Midyear examination results for group 3 students.

Table 1. The distribution of the 3 groups according to sex.

\begin{tabular}{|c|c|c|c|c|}
\hline Group & Male & Female & Total no. & p-value \\
\hline 1 & $\begin{array}{c}2 \\
(7.1 \%)\end{array}$ & $\begin{array}{c}26 \\
(92.9 \%)\end{array}$ & $\begin{array}{c}28 \\
(26.1 \%)\end{array}$ & $0.001(\mathrm{~S})$ \\
\hline 2 & $\begin{array}{c}30 \\
(71.4 \%)\end{array}$ & $\begin{array}{c}12 \\
(28.6 \%)\end{array}$ & $\begin{array}{c}42 \\
(39.1 \%)\end{array}$ & $0.005(\mathrm{~S})$ \\
\hline 3 & $\begin{array}{c}24 \\
(64.9 \%)\end{array}$ & $\begin{array}{c}13 \\
(35.1 \%)\end{array}$ & $\begin{array}{c}37 \\
(34.6 \%)\end{array}$ & $0.070(\mathrm{NS})$ \\
\hline & 56 & 51 & 107 & \\
\hline
\end{tabular}

p-value is significant if $<0.05$ using Z-test one preparation. 
Table 2. The comparison of the risk factors between groups 2 and 3.

\begin{tabular}{|c|c|c|c|c|}
\hline & Risk factor & $\begin{array}{l}\text { Group } 2 \\
(\text { No.=42) }\end{array}$ & $\begin{array}{l}\text { Group } 3 \\
\text { (No.=37) }\end{array}$ & p-value \\
\hline $1-$ & Age (years ) & $7-12(9.5 \pm 1.9)$ & $7-10(8.5 \pm 1.3)$ & $0.009(\mathrm{~S})$ \\
\hline $2-$ & sex & $\begin{array}{c}\text { Male }=30(71.4 \%) \\
\text { Female }=12(28.6 \%)\end{array}$ & $\begin{array}{c}\text { Male }=24(64.9 \%) \\
\text { Female }=13(35.1 \%)\end{array}$ & 0.531 (NS) \\
\hline $3-$ & Number of brothers & $2.1 \pm 1.7$ & $1.6 \pm 0.9$ & 0.113 (NS) \\
\hline 4- & Number of sisters & $1.7 \pm 1.5$ & $1.4 \pm 1$ & 0.306 (NS) \\
\hline $5-$ & $\begin{array}{l}\text { Job of Father } \\
\text {-Government employee } \\
\text {-Self employed }\end{array}$ & $\begin{array}{l}21(50 \%) \\
21(50 \%)\end{array}$ & $\begin{array}{c}5(13.5 \%) \\
32(86.5 \%)\end{array}$ & $0.003(\mathrm{~S})$ \\
\hline $6-$ & $\begin{array}{l}\text { Job of Mother } \\
\text {-Employed } \\
\text {-House wife }\end{array}$ & $\begin{array}{c}5(11.9 \%) \\
37(88.1 \%)\end{array}$ & $\begin{array}{c}2(5.4 \%) \\
35(94.6 \%)\end{array}$ & 0.310 (NS) \\
\hline
\end{tabular}

Unpaired $\mathrm{t}$-test was used for the mean and chi - square test was used for the $\%$.

Table 3. The comparison of the risk factors between group 1 and group 3 .

\begin{tabular}{|c|c|c|c|c|}
\hline & Risk factor & $\begin{array}{l}\text { Group } 1 \\
(\text { No.=28) }\end{array}$ & $\begin{array}{l}\text { Group } 3 \\
\text { (No.=37) }\end{array}$ & p-value \\
\hline $1-$ & Age (ys ) & $7-8(7.5 \pm 0.7)$ & $7-10(8.5 \pm 1.3)$ & $0.001(\mathrm{~S})$ \\
\hline $2-$ & sex & $\begin{aligned} \text { Male } & =2(7.1 \%) \\
\text { Female } & =26(92.9 \%)\end{aligned}$ & $\begin{array}{c}\text { Male }=24(64.9 \%) \\
\text { Female=13 }(35.1 \%)\end{array}$ & $0.001(\mathrm{~S})$ \\
\hline 3- & Number of brothers & $2.3 \pm 1.8$ & $1.6 \pm 0.9$ & $0.044(\mathrm{~S})$ \\
\hline 4- & Number of sisters & $1.8 \pm 1.1$ & $1.4 \pm 1$ & 0.131 (NS) \\
\hline $5-$ & $\begin{array}{l}\text { Job of Father } \\
\text {-Government employee } \\
\text {-Self employed }\end{array}$ & $\begin{array}{c}6(21.4 \%) \\
22(78.6 \%)\end{array}$ & $\begin{array}{c}5(13.5 \%) \\
32(86.5 \%)\end{array}$ & 0.564 (NS) \\
\hline $6-$ & $\begin{array}{l}\text { Job of Mother } \\
\text {-Employed } \\
\text {-Housewife }\end{array}$ & $\begin{array}{c}4(14.3 \%) \\
24(85.7 \%)\end{array}$ & $\begin{array}{c}2(5.4 \%) \\
35(94.6 \%)\end{array}$ & 0.221 (NS) \\
\hline
\end{tabular}

Unpaired $\mathrm{t}$-test was used for the mean and chi - square test was used for the \%.

Table 4 (A). Al-Thawra school for boys (9 students).

\begin{tabular}{|c|c|c|}
\hline Social interaction difficulties & Speech and language delay & Conduct disorder \\
\hline Aloof, own world ** & $\begin{array}{l}\text { Pulls parents aside when want } \\
\text { something }\end{array}$ & $\begin{array}{l}\text { Attachment to unusual objects } \\
\text { (hair, stings) }\end{array}$ \\
\hline Temper tantrum* & Monotonus speech with wrong pausing** & $\begin{array}{c}\text { Stubborn about rituals and resist } \\
\text { changes }^{* * *}\end{array}$ \\
\hline $\begin{array}{l}\text { Abnormal joy expressions on } \\
\text { seeing parents * }\end{array}$ & Difficulty of understanding basic things ${ }^{* *}$ & $\begin{array}{l}\text { Difficulty in stopping repetitive } \\
\text { boring conversation }\end{array}$ \\
\hline Poor eye contact ${ }^{*}$ & Difficulty of expressing needs ** & Hand flapping *** \\
\hline Ignores when called * & $\begin{array}{l}\text { No spontaneous imitation of speech and } \\
\text { communication ** }\end{array}$ & Spinning objects ** \\
\hline $\begin{array}{l}\text { Lack curiosity about the } \\
\text { environment * }\end{array}$ & Produces unusual noises * & Restricted interest ** \\
\hline \multirow[t]{4}{*}{ Lack of ability to imitate ${ }^{\star}$} & Voice louder than usual ${ }^{*}$ & Head banging ** \\
\hline & Uses language inappropriately * & Obsessed with objects * \\
\hline & Loss of acquired speech * & \\
\hline & Cannot sustain conversation* & \\
\hline
\end{tabular}

${ }^{*}=1$ student,${ }^{* *}=2$ students, ${ }^{* * *}=3$ students. 
Table 4 (B). Al -Ghazaly school for girls (7 students).

\begin{tabular}{|c|c|c|}
\hline $\begin{array}{c}\text { Social interaction difficulties } \\
\text { frequently **** }\end{array}$ & Speech and language delay & Conduct disorder \\
\hline Aloof, own world * & Difficulty in understanding basic things * & Nil \\
\hline $\begin{array}{c}\text { Ignores when called and not turning head } \\
\text { to voice* }\end{array}$ & Cannot sustain conversation * & \\
\hline
\end{tabular}

${ }^{*}=1$ student,${ }^{* * * *}=5$ students (about $75 \%$ of students).

Table 4 (C). Abi-Tamam school (21 students).

\begin{tabular}{|c|c|c|}
\hline Social interaction difficulties & Speech and language delay & Conduct disorder \\
\hline Aloof, own world (7M, 4F) & Loss of acquired speech (3 M) & $\begin{array}{c}\text { Obsessed with objects (numbers } \\
\text { \& weather) }(4 \mathrm{M}, 1 \mathrm{~F})\end{array}$ \\
\hline $\begin{array}{l}\text { Lack of curiosity about the } \\
\text { environment }(4 \mathrm{M}, 3 \mathrm{~F})\end{array}$ & Produces unusual noises (3 M) & $\begin{array}{l}\text { Interests in toy parts } \\
(3 \mathrm{M}, 2 \mathrm{~F})\end{array}$ \\
\hline Ignores when called $(5 \mathrm{M}, 1 \mathrm{~F})$ & $\begin{array}{l}\text { Difficulty of understanding basic things } \\
\qquad(2 \mathrm{M}, 1 \mathrm{~F})\end{array}$ & $\begin{array}{l}\text { Arranging toy in rows } \\
\qquad(2 \mathrm{M})\end{array}$ \\
\hline hates crowds $(4 \mathrm{M}, 1 \mathrm{~F})$ & Repetitive language (2 M, 1F) & Restricted interest (2M) \\
\hline Excessive fear of noises $(2 \mathrm{M}, 2 \mathrm{~F})$ & Cannot sustain conversation (2 M) & \\
\hline $\begin{array}{l}\text { Facial expression not fit the situation } \\
\qquad(3 \mathrm{M})\end{array}$ & $\begin{array}{l}\text { Pulls parents aside when wants } \\
\text { something }(1 \mathrm{M}, 1 \mathrm{~F})\end{array}$ & \\
\hline $\begin{array}{c}\text { Abnormal joy expressions on seeing } \\
\text { parents }(2 \mathrm{M}, 1 \mathrm{~F})\end{array}$ & $\begin{array}{c}\text { No spontaneous imitation of speech or } \\
\text { communication ( } 1 \mathrm{M})\end{array}$ & \\
\hline Ignores pain $(1 \mathrm{M}, 1 \mathrm{~F})$ & $\begin{array}{l}\text { Monotonus speech wrong pausing } \\
(1 \mathrm{M})\end{array}$ & \\
\hline Lack of ability to imitate (1M, 1F) & Repeat heard words (1F) & \\
\hline Poor eye contact $(2 \mathrm{M})$ & Difficulty of expressing needs (1M) & \\
\hline \multicolumn{3}{|l|}{ Inappropriately anxious $(1 \mathrm{M}, 1 \mathrm{~F})$} \\
\hline Temper tantrum (1M) & & \\
\hline Inappropriately laughing(1M) & & \\
\hline
\end{tabular}

Table (5): Marks in Arabic language of midyear examination for group 3 students.

\begin{tabular}{|c|c|c|c|c|}
\hline $\begin{array}{c}\text { Al- Thawra } \\
\text { (1) } \\
\text { no. }=9\end{array}$ & $\begin{array}{c}\text { Al-Ghazaly } \\
(2) \\
\text { no. }=7 \\
\end{array}$ & \multicolumn{2}{|c|}{$\begin{array}{c}\text { Abi - Tamam } \\
\text { (3) } \\
\text { no. }=21\end{array}$} & p- value \\
\hline 6 & 3 & 109 & 10 & \\
\hline 5 & 3 & $\begin{array}{ll}8 & 10 \\
\end{array}$ & 10 & \\
\hline 9 & 10 & $\begin{array}{ll}10 & 10\end{array}$ & 10 & \\
\hline 9 & 8 & 10 & & \\
\hline 5 & 10 & 10 & & \\
\hline 2 & 7 & 102 & & \\
\hline 2 & 10 & 10 & & \\
\hline 10 & & 10 & & \\
\hline 3 & & 8 & & \\
\hline$(5.7 \pm 3.1)$ & $(7.3 \pm 3.2)$ & $(8.9 \pm 1$ & & $0.007(\mathrm{~S})$ \\
\hline
\end{tabular}

Anova test was used $\mathrm{F}=5.725$ and then post Hoc test (Duncan), which had shown the significant difference was between 1 and 3 (0.007), but no significant difference between 1 and 2, or between 2 and 3 .

\section{DISCUSSION}

The prevalence of pervasive developmental disorders is increasing, the availability of professionals trained in childhood development disorders has greatly increased the capacity to identity and treat children with these problems ${ }^{(2)}$. The results of this study indicate that no students in the three schools had any of these disorders, although some symptoms in social interactions, defects in language, and conduct disorders had been detected among the studied sample.

There were predominance of males in all problems; also students from different social classes were involved as discussed elsewhere. ${ }^{(1,2)}$ If sex, number of brothers and sisters and job of father and mother could be considered as risk factors for these defects, significant results had been shown for some variables as in Table 2 and 3 after doing comparison between the three groups. Different problems had been found in this 
sample involving different number of students, but the commonest one was in social relationships, and that was being aloof with their own world, with little care for their surroundings. No important defect in language and speech, or in behavior could be found apart from those four students in AL-Thawra school with many problems whom their school was told to refer these students to the psychiatric research unit for further evaluation, and to help their families to cover their father absences from home, as one had married another woman, and the other two were drivers outside Mosul city. Although most of the students in the study had passed the midyear examinations successfully (about $84 \%$ ) but the interesting point in the study was the marks in Arabic language of midyear examination for some boys of AL-Thawra school who were in group (3), and this probably reflected the effect of the delay in language and speech. One of the 2 students with language problem in this school had failure in all the lessons with mark 3 out of 10 in Arabic language of the midyear examination. The other who was repeater of two years in the second class had passed the examination successfully with 5 out of 10 marks in Arabic language.

No study in Iraq of the same design was found to compare our results to, but a study was conducted in USA on 4321 children younger than ten years, to estimate the prevalence of developmental delay in cognitive, language and adaptive skills and to indentify the influence of age, sex, race, income and type of child maltreatment or placement as well to identify the prevalence of service use among children in the child welfare system. They found that the rates of developmental delay was high, and young children up to two years of age, had the higher rates of developmental delay and severe neglect emerged as the worst prognostic language indicator, while race, sex, income and type of child maltreatment did not have significant impact on developmental scores. It was difficult to compare my study with this one because of the different sample used and its small number. ${ }^{(14)}$ Another study in Canada on 4987 children aged 1 to 5 years was conducted to evaluate social and environmental determinants of poor developmental attainment among preschool children, which were found to be male sex, maternal depression, low maternal education and household low income adequacy, although this study involves a small sample, but still some social variables, like father's job and family size, could be considered as risk factors for developmental delay ${ }^{(15)}$. Thanoon MZ from Nursing College in Mosul tried to measure blood lead level among children who had been diagnosed as cases of pervasive developmental disorders in the psychiatric research unit, Collage or Medicine, University of Mosul, he found high blood lead levels in some of them ${ }^{(16)}$. A study done at 2004 in Mosul which was aiming to measure the point prevalence of mental disorders among children from 1-15 years in a sample from primary health care centers after interview, was conducted with the families visiting these centers, they had found only three cases with autism ( 2 boys and 1 girl) out of 3079 children studied $(0.1 \%)$, while in this study no full blown case of autism was detected $^{(17)}$.

\section{CONCLUSION}

1- Although no case of pervasive developmental disorder was found, still these disorders are increasing and had to be studied more.

2- Some problems in the social interactions, language, speech and conduct disorders had been seen in the school students, especially boys, and need global solutions.

3- The presence of language and speech disorders in students may affect their examination results especially in Arabic language.

\section{RECOMMENDATIONS}

1- Further wider studies of other schools in Mosul looking for any case with ASDs.

2- Working hardly with teachers of primary schools to look for problems in their students regarding social interaction, speech and behavior, after which the needed advices should be given to teachers and families including referral of these students to psychiatric unit to solve their problems.

3- Wide education programs in TV to increase awareness of people about ASDs.

4- Other wider screening questionnaire papers for other parts of the society for example Kindergarten to look for any case with developmental disorder. 


\section{Acknowledgements}

My grateful thanks, and appreciation to Prof. Dr. Elham Khattab, for her kind help, support and encouragement to continue this work. My thanks to the staff at the Psychiatric Research Unit in the College of Medicine, University of Mosul. My thanks as well to the managers and teachers of the visited schools for their help.

I would like to thank Miss. Muna M. Ahmad for her help in the statistical analysis.

\section{REFERENCES}

1. Ferrie C, Newton R, Martland T, et al. Neurology, Psychiatric disorders in childhood. In: Mclntosh N, Helms P, Smyth R, editors. Forfar Textbook of Pediatrics. $7^{\text {th }}$ edition. Australia: Churchill Livingstone; 2008.p.812,943-944, 1550-1551.

2. Shah PE, Dalton R, Boris NW. Pervasive Developmental Disorders and Childhood Psychosis. Kliegman, Nelson Textbook of Pediatrics. $18^{\text {th }}$ edition. Saunders, 2007.p. 1-7.

3. Harris W. Behavioral and Developmental Pediatrics. Examination Pediatrics. $3^{\text {rd }}$ edition. Australia: Churchill Livingstone; 2006.p. 50- 51.

4. Elias ER, Tsai AC, Manchester DK. Genetics and Dysmorphology. In: Hay WW, editor. Current Diagnosis and Treatment. $19^{\text {th }}$ edition. McGraw- Hill Companies; 2009.p. 1015.

5. Scheffer R. Psychiatric Disorders. Karen J. Marcdante. Essentials of Pediatrics. $6^{\text {th }}$ edition. Saunders; 2011.p. 77-78.

6. Stodgell CJ, Rodier PM. The tetralogy of Autism. Int J Dev Neurosci. 2005; 23 (2-3): 189-199.

7. Rutter M. Incidence of Autistic Spectrum Disorders: changes overtime and their meaning. Acta Paediatr. 2005; 94 (1): 2-15.
8. Hughes JR. A Review of Recent Reports on Autism. Epilepsy Behav. 2008; 13 (3):425-437.

9. Ives M, Munro N. Caring For a Child With Autism. Philadelphia PA USA. 2002: 14-17,23-25,55.

10. Richdale AL, Schreck KA. Sleep Problems in Autistic Spectrum Disorders. Sleep Med. Rev. 2009; 13(6): 403-411.

11. Myers SM, Johnson CP. Council on Children with Disabilities, Management of Children With Autistic Spectrum Disorders. Pediatrics. 2007; 120(5):11621182.

12. Paul D. ASD. Jan. 2011 [cited 2011 Feb]. Available from: URL:http/www.pediatricsconsultantive. com/ autism.

13. Grossmann R. The PDD assessment scale/ screening questionnaire. 2000-2004 [cited 2011 Feb]. Available from: URL:http/www.childbrain.com/ pddassess.htm.

14. Zimmer MH, Panko LM. Developmental Status and Service Use Among Children in The Child Welfare System. Arch Pediatr Adolesc Med. 2006;160:183188.

15. Dick PT, Patricia C, Cao H. Risk Markers for Poor Developmental Attainment in Young Children. Arch Pediatr Adolesc Med. 2004;158:643-649.

16. Thanoon MZ. Estimation of Lead Level among Children With Pervasive Developmental Disorders. MSc Thesis in Nursing, Nursing College, University of Mosul. 2010:52, 57-58.

17. AL-Jawadi AA, Abdul-Rhman S. Prevalence of Childhood and Early Adolescence Mental Disorders Among Children Attending PHC Centers in Mosul. BMC. J. of Public Health 2007;1-8. 


\section{APPENDIX 1}

\section{مقياس تقييم الاضطراب ألنمائي واسع الانتثار / استبيان /}

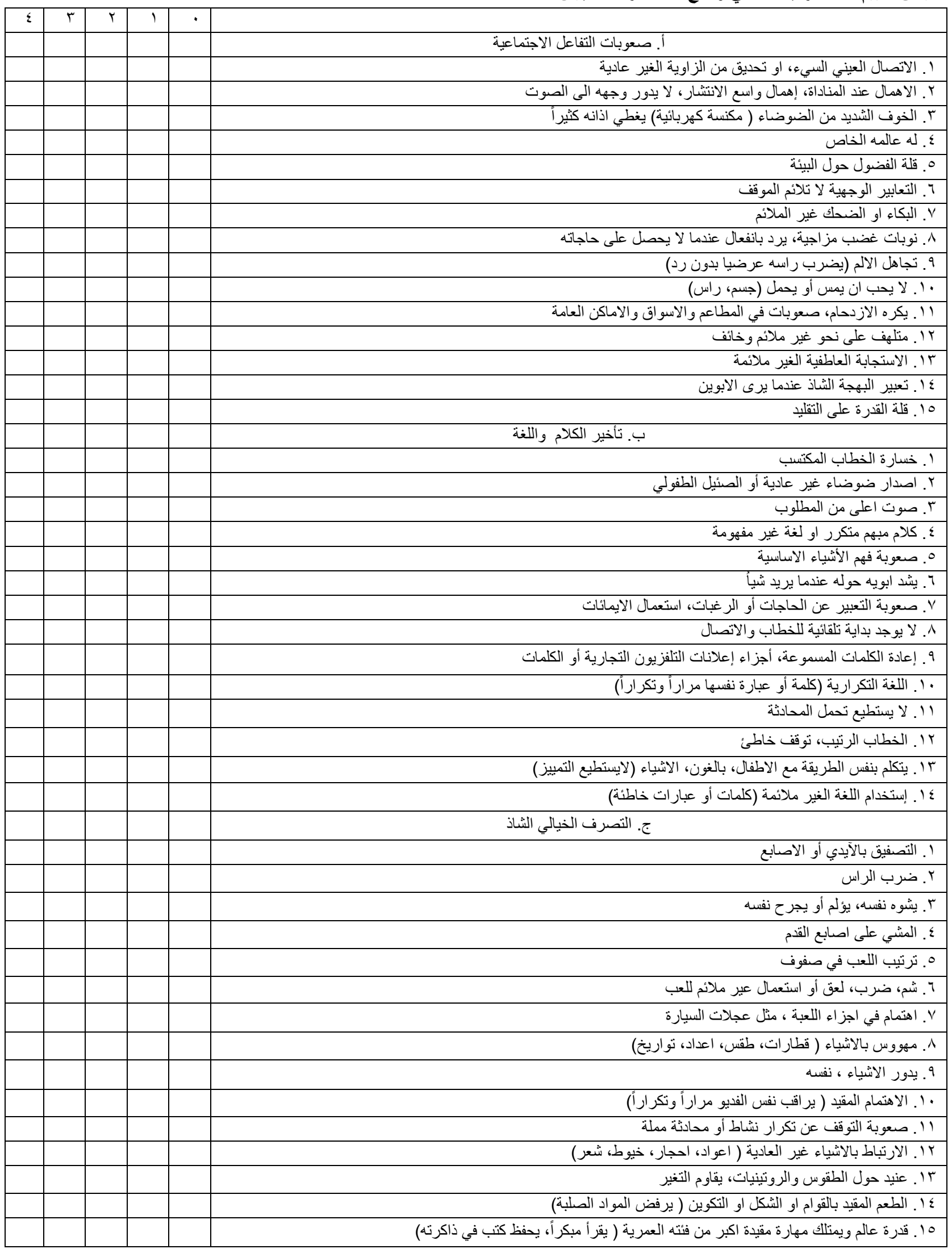




\section{APPENDIX 2}

\begin{tabular}{|c|c|c|c|c|c|}
\hline & 0 & 1 & 2 & 3 & 4 \\
\hline 1. social interaction difficulties & & & & & \\
\hline Poor eye contact or staring from unusual angle & & & & & \\
\hline Ignores when called, pervasive ignoring, not turning head to voice & & & & & \\
\hline Excessive fear of noises covers ears frequently & & & & & \\
\hline In his/her own world (aloof) & & & & & \\
\hline Lack of curiosity about the environment & & & & & \\
\hline Facial expressions don't fit situation & & & & & \\
\hline Inappropriate crying or laughing & & & & & \\
\hline Temper tantrums, overreacting when not getting his/her way & & & & & \\
\hline Ignores pain (bumps head accidentally without reacting) & & & & & \\
\hline Doesn't like to be touched or held ( body, head ) & & & & & \\
\hline Hates crowds, difficulties in restaurants and supermarkets & & & & & \\
\hline Inappropriately anxious, scared & & & & & \\
\hline Inappropriate emotional response & & & & & \\
\hline Abnormal joy expression when seeing parents & & & & & \\
\hline Lack of ability to imitate & & & & & \\
\hline 2. speech and language delay & & & & & \\
\hline Loss of acquired speech & & & & & \\
\hline Produces unusual noises or infantile squeals & & & & & \\
\hline Frequent gibberish or jargon & & & & & \\
\hline Difficulty of understanding basic things (just can't get it) & & & & & \\
\hline Pulls parents aside when wants something & & & & & \\
\hline Difficulty of expressing needs or desires, using gestures & & & & & \\
\hline No spontaneous initiation of speech & & & & & \\
\hline Repeats heard words or TV commercials & & & & & \\
\hline Repetitive language & & & & & \\
\hline Cannot sustain conversation & & & & & \\
\hline Monotonous speech, wrong pausing & & & & & \\
\hline Speaks like kids, adults, objects & & & & & \\
\hline Uses language inappropriately ( wrong words ) & & & & & \\
\hline 3. abnormal symbolic imaginary play & & & & & \\
\hline Hand or finger flapping, self stimulation & & & & & \\
\hline Head banging & & & & & \\
\hline Self mutilation, inflicting pain or injury & & & & & \\
\hline Toe walking, clumsy body posture & & & & & \\
\hline Arranging toys in rows & & & & & \\
\hline Smelling, banging, licking or other inappropriate use of toys & & & & & \\
\hline Interest in toy parts such as car wheels & & & & & \\
\hline Obsessed with objects or topics as trains, weather, numbers , dates & & & & & \\
\hline Spinning objects, self, fascination with spinning objects & & & & & \\
\hline Restricted interest, watching the same video over and over & & & & & \\
\hline Difficulty in stopping repetitive " boring" activity or conversation & & & & & \\
\hline Attachment to unusual objects, (sticks, stones, strings, or hair) & & & & & \\
\hline Stubborn about rituals and routines, resistant to change & & & & & \\
\hline Restricted taste by consistency, shape or form (refuses solids) & & & & & \\
\hline Savant ability, restricted skill superior to age group (reads earl & & & & & \\
\hline
\end{tabular}

